\title{
Kompetensi dan Kepemimpinan Dalam Mempengaruhi Kinerja Dosen STIE Serasan Muara Enim
}

\author{
Hertanudin \\ STIE Serasan Muara Enim \\ Email: herton.66@gmail.com
}

\begin{abstract}
ABSTRAK
Penelitian ini bertujuan untuk mengetahui pengaruh kompetensi dan kepemimpinan terhadap kinerja dosen STIE SERASAN Muara Enim. Rumusan masalah bagaimana kompetensi dan kepemimpinan mempengaruhi kinerja dosen? Data yang digunakan dalam penelitian ini berupa data primer dari jawaban 30 responden. Metode penarikan sampel pada penelitian ini adalah Non probability sampling dengan tipe sampling jenuh. Model analisis yang digunakan regresi linear berganda dan melalui pengujian instrumen validitas dan reliabilitas. Hasil pengujian regresi linear berganda untuk uji $F$ menunjukkan terdapat pengaruh positif dan signifikan kompetensi dan kepemimpinan terhadap kinerja sebesar 0,035. Variabel kompetensi berpengaruh signifikan terhadap kinerja sebesar 0,029 dan variabel kepemimpinan juga berpengaruh signifikan sebesar 0,057 terhadap kinerja dosen STIE SERASAN Muara Enim. Ditemukan kesesuaian teori tiap variabel dalam penelitian ini dan antar variabel serta mendukung penelitian terdahulu. Peningkatan dan penurunan kompetensi dapat mempengaruhi kinerja dosen, begitu juga peningkatan dan penurunan kepemimpinan terhadap kinerja dosen.
\end{abstract}

Kata Kunci: kompetensi, kepemimpinan, kinerja.

\section{A. PENDAHULUAN}

Untuk membentuk hakikat manusia berkualitas salah satu cara adalah melalui pendidikan, manusia yang dibutuhkan negara Indonesia sekarang dan di masa mendatang adalah manusia yang berkualitas dan berdaya saing. Untuk mewujudkan cita-cita bangsa maka perlu adanya penyelenggaraan pendidikan tinggi yang bermutu. Kualitas sumber daya manusia tetap menjadi faktor utama yang menentukan keberhasilan dan kualitas pengajaran serta pendidikan di perguruan tinggi. SDM memiliki peran penting dalam membentuk mutu lulusan maupun mutu perguruan tinggi secara keseluruhan.

Strategi SDM dalam mewujudkan pendidikan tinggi yang berkualitas dapat melalui kinerja dosen yang diperoleh melalui faktor ekternal dan faktor internal pendidik. Faktor internal antara lain terdiri dari motivasi, profesionalitas, disiplin kerja dan lainnnya, sedangkan faktor eksternal terdiri atas, lingkungan kerja, pelatihan, kepemimpinan, kompetensi, pelatihan, iklim organisasi dan lain-lain. Dalam penelitian ini faktor internal yang mempengaruhi kinerja dosen adalah kompetensi dan faktor ekternal yang mempengaruhi kinerja dosen yaitu kepemimpinan. Performance dalam bekerja di pengaruhi oleh banyak faktor, Uno (2011) menyatakan dalam peningkatan kinerja perlu dipertimbangkan melalui peningkataan profesionalitas, peningkatan motivasi kerja dan disiplin kerja yang tinggi yang berpihak pada kesejahteraan, terbuka dan menekankan pada prestasi, karena tugas terkait dan dibuktikan dengan keberhasilan pendidikan siswa.

Menurut Rusman (2010) konsep kinerja dosen sebagai cara kerja yang menyangkut 
melaksanakan tugas mengajar dapat dilihat dari indikator meliputi: kemampuan merencanakan program belajar mengajar, kemampuan melaksanakan/mengelola proses belajar mengajar dan kemampuan menilai proses belajar mengajar. Salah satu faktor yang mempengaruhi kinerja yaitu kompetensi, Mudlofir (2012) menyatakan kompetensi adalah perpaduan dari penguasaan pengetahuan, keterampilan, nilai dan sikap yang direfleksikan dalam kebiasaan berpikir dan bertindak dalam melaksanakan tugas/pekerjaannya. Dosen yang bekerja dengan kompetensi tinggi akan menghasilkan kinerja yang maksimal. Handoko (2015) menyatakan pada kenyataan pemimpin dapat mempengaruhi moral dan kepuasan kerja, keamanan, kualitas hidup, dan terutama tingkat prestasi suatu organisasi artinya dalam hal ini peran pemimpin tidak dapat lepas dari terbentuknya kinerja dosen.

Dosen merupakan komponen esensial atas berlangsungnya hidup perguruan tinggi, untuk itu dosen dituntut untuk dapat memaknai tugas, peran dan tanggungjawabnya secara maksimal. Dosen tidak hanya mampu mewujudkan tujuan perguruan tinggi tempatnya bernaung namun dosen juga harus mampu mewujudkan tujuan pendidikan nasional, yaitu mencerdaskan kehidupan bangsa, meningkatkan kualitas manusia yang terdiri atas kualitas iman dan takwa, ahlak mulia dan penguasaan ilmu pengetahuan, teknologi dan seni serta mewujudkan masyarakat Indonesia yang adil makmur dan beradab.

UNESCO (20015) menyatakan setiap proses pendidikan yang baik selalu mengandung 4 hal penting yaitu bagaimana untuk mengetahui (how to know), bagaimana untuk melakukan ( how to do), bagaimana untuk menjadi (how to be) dan bagaimana untuk hidup dalam keberagaman (how to live together). Perguruan tinggi dituntut untuk dapat mengedepankan keunggulannya secara kompetetif karena masyarakat mulai cerdas untuk memilih perguruan tinggi yang mampu memberikan jawaban atas semua harapan mereka.

Undang-undang No.14 tahun 2005 tentang guru dan dosen mensyaratkan bahwa dosen harus berpendidikan S2 dan mempunyai jabatan fungsional sekurang-kurang asisten ahli. Usaha untuk menciptakan guru yang profesional, pemerintah telah membuat aturan persyaratan untuk menjadi guru. Dalam pasal $8 \mathrm{UU}$ yang sama menyebutkan bahwa guru wajib memiliki kualifikasi akademik, kompetensi, sertifikat pendidik, sehat jasmani dan rohani, serta memiliki kemampuan untuk mewujudkan tujuan pendidikan nasional. Namum dalam kenyataannya masih sedikit guru yang memenuhi syarat tersebut, diantara 19 dosen tidak tetap pada STIE SERASAN masih terdapat dosen yang belum memiliki jenjang fungsional akademik.

Perlu upaya untuk terus meningkatkan kualitas dosen di STIE SERASAN Muara Enim agar keberadaan tetap bermanfaat bagi masyarakat Kabupaten Muara Enim dan sekitarnya melalui peningkatan kompetensi dan kepemimpinan yang baik. Data yang diperoleh dari bagian kepegawaian pada pertengahan tahun 2018 STIE SERASAN Muara Enim memiliki dosen tetap yayasan sebanyak 11 orang dan dosen tidak tetap sebanyak 19 orang. Jumlah tersebut tentunya telah disesuaikan dengan rasio dosen dan mahasiswa namun terdapat kelemahan banyaknya jumlah Dosen tidak tetap dibanding dosen tetap. Dengan tingkat pendidikan baik dosen tetap maupun 
dosen tidak tetap semuanya S2 dan belum terdapat doktor. Untuk saat ini jenjang kepangkatan/ fungsional juga belum proporsional jika dikaitkan dengan masa kerja, usia dosen, lamanya waktu kepangkatan sebelumnya. Dalam jangka waktu yang lama jumlah dosen yang bersertifikasi juga belum mencapai target.

Berdasarkan uraian di atas rumusan masalah dalam penelitian ini adalah bagaimana pengaruh kompetensi dan kepemimpinan terhadap kinerja dosen STIE SERASAN Muara Enim.

\section{B. KAJIAN PUSTAKA \\ 1) Kompetensi}

Kompetensi

merupakan

peleburan dari pengetahuan, sikap dan keterampilan yang diwujudkan dalam bentuk perbuatan. Sagala (2009) menyatakan kompetensi merupakan perpaduan dari penguasaan pengetahuan, keterampilan, nilai dan sikap yang direfleksikan dalam kebiasaan berpikir dan bertindak dalam melaksanakan tugas/pekerjaannya. Kompetensi juga merupakan suatu sifat (karakteristik) dan orang-orang (kompeten) yang memiliki kecakapan, daya (kemampuan), otoritas (kewenangan), kemahiran (keterampilan), dan pengetahuan. (Mudlofir, 2012).

Becker, Huselid \& Ulrich dalam Marwansyah (2010) Kompetensi berarti "comperencies refers to on individual's knowladge skills, abilties, or personality characterristics that directly influence hi or her job performance" (kompetensi adalah pengetahuan, keterampilan, kemampuan atau karakteristik kepribadian seseorang yang secara langsung mempengaruhi kinerjanya). Dharma (2012) mengemukakan kompetensi adalah apa yang dibawa seseorang dalam pekerjaannya dalam bentuk, jenis dan tingkatan yang berbeda. Atribut tertentu itu (pengetahuan, keahlian dan kepiawaian) yang dibutuhkan untuk melaksanakan berbagai tugas yang berhubungan dengan suatu pekerjaan. McClelland dalam Rivai dan Sagala (2011) kompetensi sebagai karakteristik yang mendasar yang dimiliki seseorang yang berpengaruh langsung terhadap, atau dapat memprediksikan kinerja yang sangat baik. Dalam Undang-Undang Guru dan Dosen Nomor 14 Tahun 2005 dijelaskan bahwa kompetensi adalah seperangkat pengetahuan, ketrampilan dan perilaku yang harus dimiliki, dihayati, dan dikuasai oleh guru atau dosen dalam melaksanakan tugas keprofesionalan, sehingga dapat melakukan perilaku-perilaku kognitif, afektif, dan psikomotor dengan sebaikbaiknya. Kompetensi merupakan perpaduan dari pengetahuan, keterampilan, nilai dan sikap yang direfleksikan dalam kebiasaan berpikir dan bertindak

\section{2) Kepemimpinan}

Seorang yang mempunyai kemampuan untuk mempengaruhi orang lain dalam kerjanya dengan menggunakan kekuasaan proses tersebt dikatakan kepemimpinan. Gunawan (2017) menyatakan kepemimpinan adalah suatu proses untuk mempengaruhi dan memberikan aspirasi serta mengarahkan tindakan seseorang atau kelompok untuk mencapai tujuan yang diharapkan. Kepemimpinan merupakan proses dimana individu mempengaruhi anggota-anggota kelompok untuk pencapaian tujuan kelompok atau organisasi (memotivasi individu tanpa ada unsur paksaan).

Nawawi dalam Gunawan (2017) menyatakan ada tiga unsur dalam kepemimpinan 1) orang yang 
memimpin, yakni orang mampu mempenagruhi orang lain, 2) orang yang dipimpin, yakni orang dipengaruhi orang lain, 3) tujuan yang hendak dicapai. Selanjutnya Lassey dalam Gunawan (2017) menyatakan terdapat dua fungsi menjalankan tugas dan fungsi pemeliharaan. Siagian (2011) menyatakan terdapat lima tipe kepemimpinan yaitu otoraktis, militeristis, paternalistis, karismatis, dan demokratis.

Handoko (2013) menyatakan bahwa kenyataannya pemimpin dapat mempengaruhi moral dan kepuasan kerja, keamanan, kualitas hidup kerja dan terutama tingkat prestasi suatu organisasi. Pemimpin yang efektif adalah yang mempunyai sifat-sifat atau kualitas tertentu yang diinginkan seperti karisma, berpandangan ke depan, intensitas, dan keyakinan diri. Kepemimpinan yang efektif dapat memberikan pengarahan terhadap usaha-usaha semua pekerja dalam mencapai tujuan organisasi.

\section{3) Kinerja Dosen}

\section{a. Kinerja}

Handoko (2013), menyatakan kinerja merupakan suatu fungsi dari motivasi dan kemampuan untuk menyelesaikan tugas atau pekerjaan seseorang sepatutnya memiliki derajat kesediaan dan tingkat kemampuan tertentu. Kesediaan dan kemampuan seseorang tidaklah cukup efektif untuk mengerjakan sesuatu tanpa pemahaman yang jelas tentang apa yang akan dikerjakan dan bagaimana mengerjakannya. Dipertegas Mangkunegara (2015) Kinerja adalah hasil kerja secara kualitas dan kuantitas yang dicapai oleh seorang pegawai dalam melaksanakan tugasnya sesuai dengan tanggung jawab yang diberikan kepadanya. Kinerja juga dapat juga dikatakan sebagai hasil yang ditampilkan oleh
Pegawai tersebut dalam pelaksanaan tugas sehari-hari. Jadi untuk mengukur kinerja seseorang dapat dilihat pada sitiasi dan kondisi kerjanya sehari-hari. Selanjutnya dipertegas Rivai (2011) kinerja adalah suatu tampilan keadaan secara utuh atas perusahaan selama periode waktu tertentu, merupakan hasil atas prestasi yang dipengaruhi oleh kegiatan operasional perusahaan dalam memanfaatkan sumber-sumber daya yang dimiliki.

Selanjutnya Mangkunegara (2013), menyatakan indikator yang dapat digunakan untuk mengukur kinerja pegawai adalah dengan melihat hasil kerjanya secara kualitas dan kuantitas yang dicapai oleh seorang pegawai dalam melaksanakan tugasnya sesuai dengan tanggung jawab yang diberikan kepadanya yaitu berupa 1) kualitas kerja, pegawai yang memiliki kinerja yang baik, maka dapat dilihat dari kualitas kerja, akurasi kerja, dan marginal kesalahan. 2)kuantitas kerja, pegawai selalu berusaha untuk menyelesaikan tugas dengan hasil yang benar, maksimal, dan tepat waktu. 3) tanggung jawab, egawai bertanggung jawab dalam menyelesaikan tugas-tugas, memiliki rencana kerja yang jelas, berusaha untuk merealisasikan rencana kerja.

\section{b. Pengaruh kompetensi dan kepemimpinan terhadap kinerja Dosen}

Penelitian ini ingin melihat research gap dan pembuktian hipotesis penelitian terdahulu yang dilakukan Pramudyo (2010) menganalisis faktor-faktor yang mempengaruhi kinerja dosen negeri pada Kopertis Wilayah V Yogjakarta. Hasil penelitiannya menyatakan bahwa apabila dosen mempunyai motivasi dan kompetensi dan didukung adanya kepemimpinan yang baik maka akan dapat meningkatkan kinerja dosen. 
Harsono (2013) Menunjukkan bahwa secara keseluruhan dan bersamasama kompetensi, motivasi kondisi sarana dan prasarana serta teknologi dan informasi berkonstribusi secara simultan dan signifikan terhadap kinerja dosen.

Afandi dan Supeno (2016) melakukan penelitian berjudul influence of competence, organizational culture and work environment to teacher's performance as well its implikasi on grad competence of state senior islam school on Padang city. Hasil analisis verifikasi menunjukkan ada pengaruh signifikan kompetensi guru terhadap kinerja guru sebesar $21 \%$, perilaku organisasi sekolah berpengaruh sebesar $84 \%$ terhadap kinerja guru dan lingkungan kerja sebesar 56\%. Arifin (2015) The influence, motivation and organizational culture to high scholl teacher job satisfaction and performance. Temuan menunjukkan bahwa kompetensi dan kepuasan kerja mempengaruhi kinerja guru secara positif dan signifikan.
Berdasarkan kajian teori dan penelitian terdahulu maka hipotesis yang diajukan dalam penelitian ini adalah:

H1:Kompetensi dan kepemimpinan berpengaruh signifikan terhadap kinerja dosen STIE SERASAN Muara Enim.

$\mathrm{H} 2$ :Kompetensi berpengaruh signifikan terhadap kinerja dosen STIE SERASAN Muara Enim.

H3: Kepemimpinan berpengaruh signifikan terhadap kinerja dosen STIE SERASAN Muara Enim.

\section{c. Model Penelitian}

Pemikiran yang melandasi penelitian ini pada hakekatnya adalah kompetensi dan kepemimpinan akan berpengaruh pada kinerja dosen, seorang dosen yang mempunyai kompetensi yang tinggi dan sesuai kualifikasi yang ditetapkan serta kepemimpinan yang baik maka akan semakin tinggi pula kinerja dosen, model penelitian ini dapat digambarkan sebagai berikut:

Gambar 1

Model Penelitian

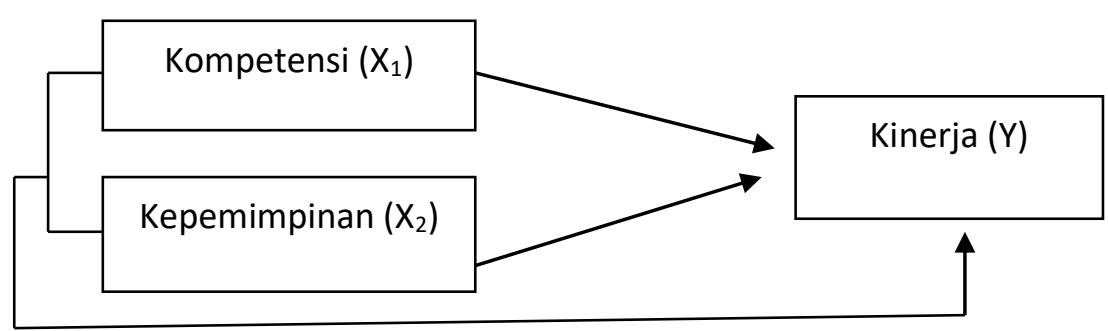

C. METODE PENELITIAN

\section{Populasi, Sampel dan Metode} Sampling

Kelompok populasi (Population frame) merupakan kumpulan semua elemen dalam populasi di mana sampel diambil. Populasi dalam penelitian ini adalah seluruh dosen di STIE SERASAN sebanyak 30 orang. Sampel adalah bagian dari jumlah dan karakteristik yang dimiliki oleh populasi. Jika populasi kurang dari 100 diambil semua, sedangkan bila lebih dari 100 dapat diambil antara 10\% $15 \%$ atau $20 \%-25 \%$ lebih, setidaktidaknya tergantung dari kemampuan peneliti. Mengingat besar populasi dalam penelitian ini kurang dari 100 , maka seluruh responden dalam ini yang berjumlah 30 orang dijadikan sampel. Metode penarikan sampel pada penelitian ini adalah Non 
probability sampling dengan tipe sampling jenuh yaitu tehnik penentuan sampel bila semua anggota populasi digunakan sebagai sampel.

\section{HASIL PENELITIAN}

\section{1) Pengujian Instrumen}

Uji validitas dilakukan untuk mengukur tingkat kevalidan atau kesahihan suatu instrumen secara empiris hasil menunjukkan bahwa keseluruhan butir item dinyatakan valid dengan menggunakan rujukan bahwa besaran korelasi tiap butir dalam mengukur variabel 0,360. Uji Reliabilitas dilakukan untuk mengukur konsistensi dan stabilitas dari skor (skala pengukuran). Kriteria yang digunakan untuk mengetahui tingkat reliabilitas adalah besarnya nilai cronbach's alpha. Instrumen penelitiann reliabel apabila hasil pengujian menunjukkan alpha lebih besar dari 0,70. Hasil empiris pengujian dapat dilihat pada Tabel 1 yang menunjukkan bahwa keseluruhan item reliabel atau konsisten sebagai alat ukur.

Tabel 1

Hasil Pengujian Reliabilitas

\begin{tabular}{|c|l|c|c|}
\hline No & \multicolumn{1}{|c|}{ Variabel } & $\begin{array}{c}\text { Cronbach's } \\
\text { Alpha }\end{array}$ & Keterangan \\
\hline 1 & Kompetensi & 0,785 & Reliabel \\
\hline 2 & Kepemimpinan & 0,815 & Reliabel \\
\hline 3 & Kinerja & 0,779 & Reliabel \\
\hline
\end{tabular}

Sumber: Hasil pengolahan data, 2018

2) Pengujian Asumsi Klasik

Hasil uji normalitas data dan uji multikolinearitas dapat di lihat pada tabel berikut ini:

Tabel 2

Hasil Uji Normalitas dan Uji Multikolinearitas

\begin{tabular}{|l|c|l|c|c|c|}
\hline Variabel & \multicolumn{2}{|c|}{ Normalitas } & \multicolumn{2}{c|}{ Multikolinearitas } \\
\hline & $\begin{array}{l}\text { Sig 2- } \\
\text { tailed }> \\
\text { 0,05 }\end{array}$ & Kesimpulan & VIF & Tolerance & Kesimpulan \\
\hline Kompetensi & 0,397 & Normal & 1,028 & 0,973 & $\begin{array}{c}\text { Tidak terjadi } \\
\text { multikolinearitas }\end{array}$ \\
\cline { 1 - 4 } Kepemimpinan & 0,621 & Normal & $1,0,27$ & 0,976 & \\
\hline Kinerja & 0,805 & Normal & & & \\
\cline { 1 - 3 }
\end{tabular}

Sumber: Hasil pengolahan data, 2018

Berdasarkan hasil perhitungan di atas menunjukkan bahwa semua data variabel normal karena nilai Sig 2tailed variabel independen dan dependen lebih besar dari 0,05. Hasil pengujian multikolinearitas juga menunjukkan bahwa semua data tidak terjadi multikolinearitas karena nilai VIF $<10$ dan nilai tolerance $>0,10$.

\section{3) Analisis Regresi Linear Berganda}

Analisis dalam penelitian ini dilakukan dengan analisis regresi berganda, dapat dilihat pada tabel berikut ini. 
Tabel 3

Hasil Analisis Regresi Linear Berganda

\begin{tabular}{|c|r|r|r|}
\hline \multirow{2}{*}{ Model } & \multicolumn{2}{|c|}{$\begin{array}{c}\text { Unstandardized } \\
\text { Coefficients }\end{array}$} & $\begin{array}{c}\text { Standardized } \\
\text { Coefficients }\end{array}$ \\
\cline { 2 - 4 } & \multicolumn{1}{|c|}{ B } & \multicolumn{1}{c|}{ Std. Error } & \multicolumn{1}{c|}{ Beta } \\
\hline 1 (Constant) & 1,108 & 0,630 & 0,270 \\
Kompetensi & 0,276 & 0,176 & 0,342 \\
Kepemimpinan & 0,376 & 0,189 & \\
\hline
\end{tabular}

Sumber: Hasil pengolahan data, 2018

Berdasarkan hasil perhitungan analisis regresi linear berganda diproleh hasil konstanta 1,108 artinya dengan atau tanpa kompetensi dan kepemimpinan kinerja tetap terbentuk sebesar 1,108. Kompetensi dan kepemimpinan positif berpengaruh terhadap kinerja sebesar 0,276 dan 0,376 .

\section{4) Pengujian Hipotesis}

Pengujian hipotesis untuk mengetahui pengaruh secara simultan dan parsial variabel independen terhadap variabel dependen dapat di lihat pada Tabel berikut ini.

Tabel 4

Hasil Uji F dan Uji t

\begin{tabular}{|cc|c|c|r|r|c|}
\hline & Variabel & F hitung & Sig. F & t Hitung & Sig t & Keterangan \\
\hline 1 & Kompetensi & \multirow{2}{*}{3,805} & \multirow{2}{*}{0,035} & 1,565 & 0,029 & Signifikan \\
& Kepemimpinan & & 1,985 & 0,057 & Signifikan \\
\hline
\end{tabular}

Sumber: Hasil pengolahan data, 2018

Berdasarkan perhitungan Tabel 4 diperoleh nilai signifikan $F$ sebesar $0,035<$ sig $\alpha=0,05$ dengan nilai signifikan t kompetensi sebesar 0,029 $<$ sig a 0,05 artinya terdapat pengaruh positif dan signifikan variabel kompetensi terhadap kinerja dosen. Nilai signifikan $t$ variabel kepemimpinan sebesar 0,057 artinya terdapat pengaruh positif dan signifikan variabel kepemimpinan terhadap kinerja dosen.

\section{E. PEMBAHASAN}

Hipotesis 1 menyatakan kompetensi dan kepemimpinan berpengaruh positif dan signifikan terhadap kinerja dosen STIE SERASAN Muara Enim dapat diterima dengan nilai signifikan $\mathrm{F}$ sebesar 0,035 < sig a 0,05 hal itu menunjukkan bahwa peningkatan kompetensi dan kepemimpinan dosen secara bersamasama akan meningkatkan kinerja STIE SERASAN Muara Enim.

Hipotesis 2 menyatakan kompetensi berpengaruh positif dan signifikan terhadap kinerja dosen STIE SERASAN Muara Enim dapat diterima dengan nilai signifikan $\mathrm{t}$ kompetensi sebesar $0,029<\operatorname{sig}$ a 0,05 hal itu menunjukkan bahwa peningkatan kompetensi dosen akan meningkatkan kinerja dosen STIE SERASAN Muara Enim.

Hal sama juga pada hipotesis 3 yang menyatakan kepemimpinan berpengaruh positif dan signifikan terhadap kinerja dosen STIE SERASAN Muara Enim dapat diterima dengan nilai signifikan $t$ kompetensi sebesar $0,057<\operatorname{sig}$ a 0,05 hal itu menunjukkan bahwa peningkatan kepemimpinan akan meningkatkan 
kinerja dosen STIE SERASAN Muara Enim.

Secara teoritis diungkapkan bahwa kinerja dipengaruhi banyak faktor baik faktor internal maupun eksternal. Semakin tinggi kompetensi serorang dosen maka semakin baik tampilan kerja/ kinerja dosen. Didukung dengan kepemimpinan yang maksimal dari pimpinan tempat dosen mengabdi. Perlu pemahaman pentingnya bagi dosen untuk meningkatkan kompetensi diri dalam bentuk kompetensi pedagogik, kompetensi kepribadian, kompetensi profesional dan kompetensi sosial. Kompetensi yang dimiliki dosen akan mendorong dosen menjadi profesional dan bertanggung jawab atas tugastugas dan kewajiban sebagai dosen yang tertuang dalam TriDarma Perguruan tinggi. Dosen dituntut untuk profesional dengan memiliki jenjang fungsional akademik (JFA) dan bersertifikasi dalam bentuk sertifikasi dosen.

$\begin{array}{ccc}\begin{array}{c}\text { Selain faktor internal dalam } \\ \text { bentuk }\end{array} & \text { kompetensi, } & \text { dosen }\end{array}$
memerlukan kepemimpinan yang baik. Untuk itu diperlukan pimpinan yang mampu memotivasi dan mengatur dosen untuk memahami tugas dan tanggungjawabnya sebagai dosen. Seorang pemimpin yang setiap arahan dipatuhi semua bawahan dengan penuh kesadaran. Karakter pimpinan bukanlah hal utama untuk dipatuhi, namun dosen memerlukan sarana dan prasarana yang dapat memfasilitasi kegiatan terkait dengan peningkatan kualitas kinerja dosen.

\section{F. KESIMPULAN DAN SARAN}

Berdasarkan hasil penelitian di atas, disimpulkan bahwa terdapat penelitian ini membuktikan hipotesis 1 yang menyatakan kompetensi dan kepemimpinan secara simultan berpengaruh positif dan signifikan terhadap kinerja dosen STIE SERASAN Muara Enim. Juga membuktikan hipotesis 2 dan hipotesis 3 yang menyatakan kompetensi dan kepemimpinan secara parsial berpengaruh positif dan signifikan terhadap kinerja dosen STIE SERASAN Muara Enim.

Rekomendasi bagi dosen untuk terus meningkatkan kinerja dengan mengaplikasikan faktor internal dari dalam diri dan faktor eksternal yang dapat meningkatkan kinerja dosen. Dosen sebaiknya aktif dan rutin memenuhi kewajiban mekalsanakan kegiatan TriDarma perguruan tinggi untuk terus meningkatkan jenjang fungsional. Menulis jurnal ilmiah dan mengikuti pelatihan-pelatihan mendukung peningkatan kualitas diri agar dapat berpotensi mendapatkan sertifikat dosen profesional (sertifikasi dosen) yang secara otomatis juga dapat meningkatkan penghasilan.

Keterbatasan dalam penelitian ini tidak dapat mengetahui pengaruh dominan variabel independen terhadap kinerja karena model yang dianalisis hanya kompetensi dan kepemimpinan, perluasan objek model yang diteliti tentunya dapat menjawab semua permasalahan secara maksimal. Objek penelitian sebaiknya juga di lakukan pada sekolah teknik karena di bawah naungan yayasan yang sama dan kepemimpinan, tujuannya agar jumlah sampel bertambah dan hasil jawaban angket lebih kompleks.

\section{DAFTAR PUSTAKA}

Afandi, Pandi \& Supeno, Bambang. (2016). The Influence of Competence, Organization Culture and Work Environment to Teacher's Performace As Well Its Implication on Grad Competence of State Senior Islam School on 
Padang City. International Journal of Bussines and Management: Vol.11(5). Hal:283295. Diakses: cc.senet.org/journal/index.php/ijb $\mathrm{m} /$ article/download/57840

Arifin, Muhammad. (2015). The Influence of Competence, Motivation and Organisational Culture ti High School Teacher Job Satisfaction and Performance. International Education Studies. Vol.8 (1). Hal:38-47. Diakses: http://files.eric.ed.gov/fulltext/Eji0 60782.pdf

Arikunto, Suharsimi (2013). Prosedur Penelitian Suatu Pendekatan Praktik. Cetakan ke-15. Bandung: Rineka Cipta.

Dharma, Surya. (2012). Manajemen Kinerja Filsafah Teori dan Penerapannya. Yogjakarta: Pustaka belajar

Gunawan, Imam, Benti Noor Djum Djum. (2017). Manajemen Pendidikan Suatu Pengantar Praktik. Bandung: Alfabeta.

Handoko, T, Hani (2013). Manajemen Personalia dan SDM. Yogyakarta: BPFE

Harsono, Setijo. (2013). Analisis Faktor-Faktor yang Mempengaruhi Kinerja Dosen dan Implikasinya pada Kesejahteraan Dosen Perguruan Tinggi Maritim. Jurnal Kontigensi. Vol.1(1) Juni 2013. Hal 14-24. Diakses: jurnal.dim.unpas.web.id/index.ph $\mathrm{p} / \mathrm{JIMK} /$ article/download/30/30
Mangkunegara, Prabu, Anwar (2013). Manajemen SDM Perusahaan. Bandung: Remaja Rosdakarya.

Mudlofir, Ali. (2012). Pendidik Profesional. (cet.1). Jakarta, Indonesia: Rineka Cipta.

Pramudyo, Anung. (2010). Analisis Faktor-Faktor yang Mempengaruhi Kinerja Dosen Negeri pada Kopertis Wilayah $\mathrm{V}$ Yogjakarta. JBTI. Vol.1(1) hal: 111.

Diakses:download.portalgaruda.o rg/article.php?article=9974\&ud,64 4

UNESCO. (2011). Pendidikan Usia Dini dan kebijakan Keluarga. Jakarta: unesdoc.unesco.org

Rivai, Veitzhal \& Ella, Jauvani Sagala.(2011). Manajemen Sumber Daya Manusia Untuk Perusahaan : Dari Teori ke Praktik. Jakarta: RajaGrafindo Persada

Rusman. (2010). Model-model Pembelajaran, Mengembangkan Profesionalisme Guru. Jakarta: Rajawali Pers.

Sagala, Syaiful. (2009). Kemampuan Profesional Guru dan Tenaga Kependidikan. (cet.2). Bandung, Indonesia: Alfabeta.

Undang-Undang No.14. (2005) tentang Guru dan Dosen. 2005. Jakarta, Indonesia: Departemen Pendidikan Nasional Republik Indonesia.

Uno, B Hamzah. (2011). Teori Kinerja dan Pengukurannya. Cetakan pertama. Jakarta, Indonesia: Bumi Aksara 